\title{
Different Presentations of Branchial Cysts: A Case Series
}

\author{
Anju $\mathrm{S}^{1^{*}}$, Sankar $\mathrm{S}^{2}$ \\ ${ }^{1}$ Junior Resident, ${ }^{2}$ Professor and Head of the Department Govt. Medical College, Kottayam, Kerala, India
}

\begin{tabular}{ll}
\hline DOI: $10.36348 /$ sjpm.2020.v05i06.005 & | Received: $31.05 .2020 \mid$ Accepted: 09.06 .2020 | Published: 30.06 .2020 \\
*Corresponding author: Anju S &
\end{tabular}

\section{Abstract}

Among the branchial cysts, those arising from second arch, which appear in the mid neck are the most common. It is followed by cysts arising from the third and fourth arch, which appears in the lower neck, supraclavicular or suprasternal location. But branchial cysts presenting as a mediastinal mass is very rare. Here we present four different clinical presentations of branchial cysts with their gross morphology and microscopic findings.

Keywords: Branchial arches, branchial cysts, mediastinal mass.

Copyright @ 2020: This is an open-access article distributed under the terms of the Creative Commons Attribution license which permits unrestricted
use, distribution, and reproduction in any medium for non-commercial use (NonCommercial, or CC-BY-NC) provided the original author and sources
are credited.
are credited.

\section{INTRODUCTION}

The development of head and neck structures commence with the formation of branchial apparatus during the $4^{\text {th }}$ week of gestation. There are 6 paired branchial arches. Each branchial arch consists of a core of mesenchyme covered externally by the ectoderm and internally by the endoderm. The $5^{\text {th }}$ arch disappears and the $6^{\text {th }}$ arch is rudimentary. Many congenital anomalies and cysts of the head and neck region are attributed to the aberrant development from these structures. Among these cysts those from the second branchial arch are the most common with a frequency of $90-95 \%$. This is followed by cysts from the $3^{\text {rd }}$ and $4^{\text {th }}$ arch with a frequency of 2-8\%. Those related to first arch appear in the preauricular area and those related to second arch appear anterior to the sternocleidomastoid muscle in the mid neck. Those related to third and fourth arch appears in the lower neck, in the suprasternal/supraclavicular location. Mediastinal location is very uncommon. The branchial anomalies can be sinuses, pouches or cysts. Branchial cysts presenting as a mediastinal mass is very rare. There are only very few documented cases of the fourth branchial arch anomaly, especially that involving the mediastinum.

\section{CASE 1}

A 51 year old female presented with fever and productive cough of 1 week duration. She was admitted in the general medicine department and treated with a diagnosis of pneumonia. She was on antibiotics for 2 weeks following which she got relieved of her symptoms. As part of the investigations for the same, CT thorax was taken. CT scan releaved a superior mediastinal cystic mass with thin septations, which had a mass effect on trachea and esophagus along with atelectatic changes in the middle and lower lobe of the right lung.

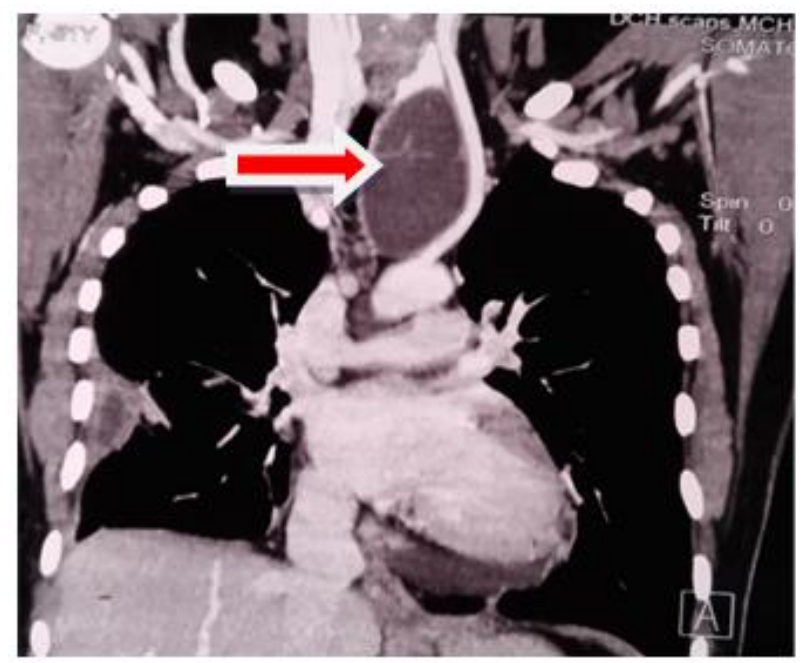

CT Thorax showing a well-defined lesion of size $4.7 \times 3.7 \times 8.5 \mathrm{~cm}$ in the superior mediastinum

A midsternal thoracotomy was carried out which revealed a cystic mass which was excised. It was weighing $50 \mathrm{gm}$, measuring $5 \times 2.5 \times 1.5 \mathrm{~cm}$.Cutting through the mass extruded creamy material and showed a biloculated cyst separted by a thick fibrous septa. Inner wall was smooth with tiny whitish specks. 


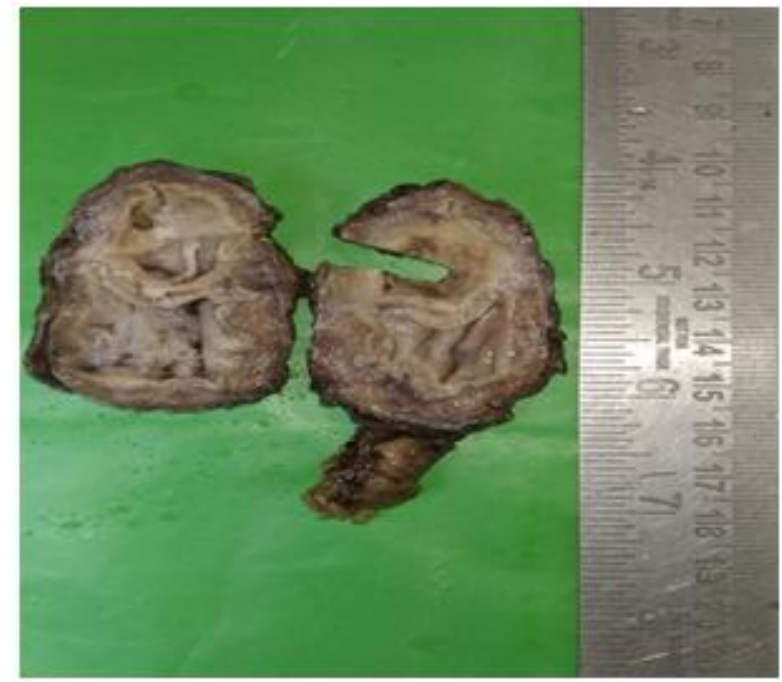

Biloculated cyst separated by thick fibrous septa

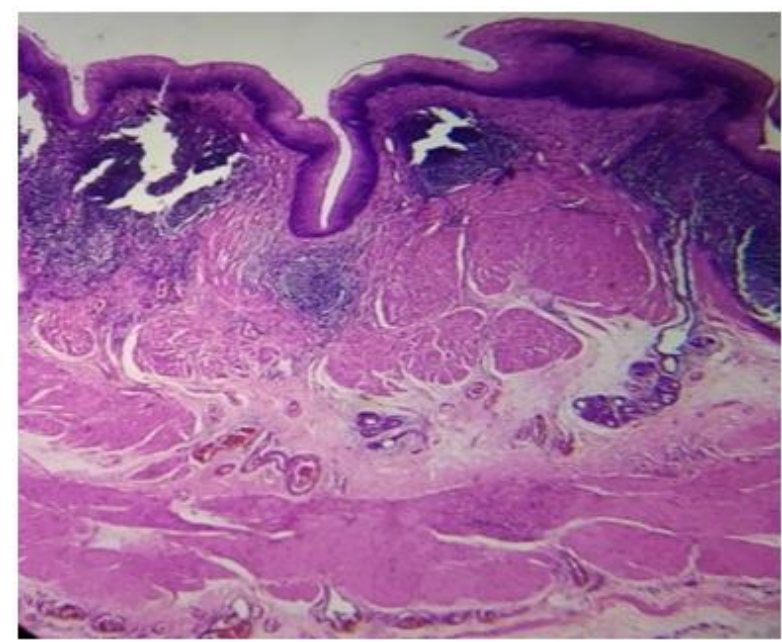

H\&E 100X: Section from cyst wall shows hyperkeratotic stratified squamous epithelium with a fibromuscular wall containing lymphoid follicles

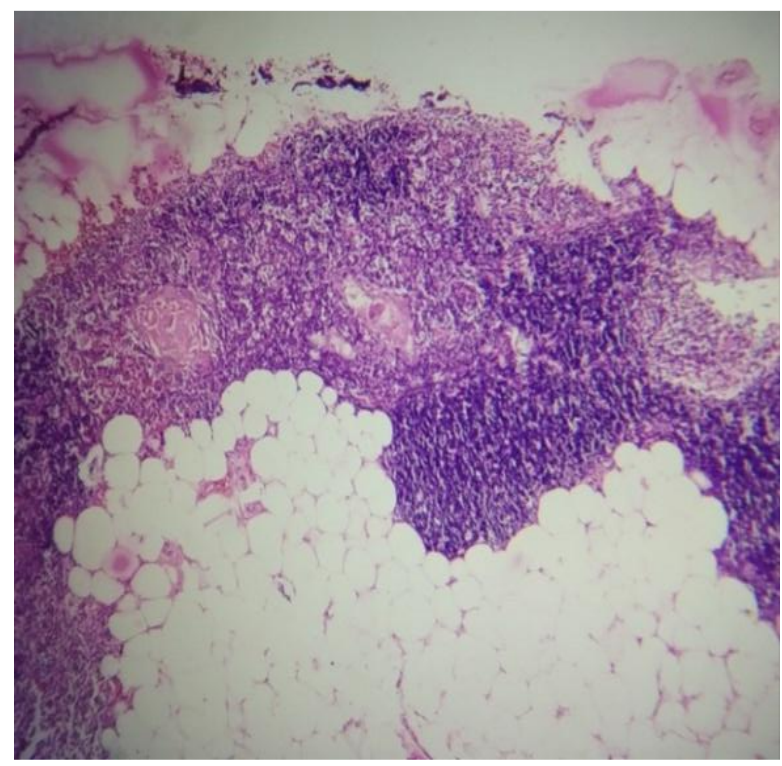

H\&E 100X: Section shows adjacent thymic tissue
H\&E stained paraffin sections showed a cyst lined by hyperkertaotic stratified squamous epithelium with fibromuscular wall containing lymphoid follicles. Areas of calcification and congested blood vessels also were seen in the wall of the cyst. Adjacent compressed thymic tissue was noted. A diagnosis of branchial cyst related to thymus possibly arising from $3^{\text {rd }}$ or $4^{\text {th }}$ branchial pouch was made. The patient is remaining healthy and free of symptoms after surgrery

\section{CASE 2}

A 21 year old male presented with swelling, rigtht side of neck since 6months, which gradually increased in size. On examination there was a swelling in the right side of neck, in the anterior border of sternocleidomastoid, measuring $5 \times 4 \times 2 \mathrm{~cm}$, which was soft in consistency with restricted mobility. MRI revealed a well-defined thin walled cystic lesion on right side of neck deep to the sternocleidomastoid muscle, suggestive of branchial cyst. It was excised and sent for histopathology.

We received a cystic mass weighing $20 \mathrm{gm}$, measuring $4.5 \times 3.5 \times 2 \mathrm{~cm}$. Cutsection extruded brown coloured fluid and showed a unilocular cyst with smooth innerwall with focal solid area measuring $1.5 \times 1.0 \times 0.8 \mathrm{~cm}$.

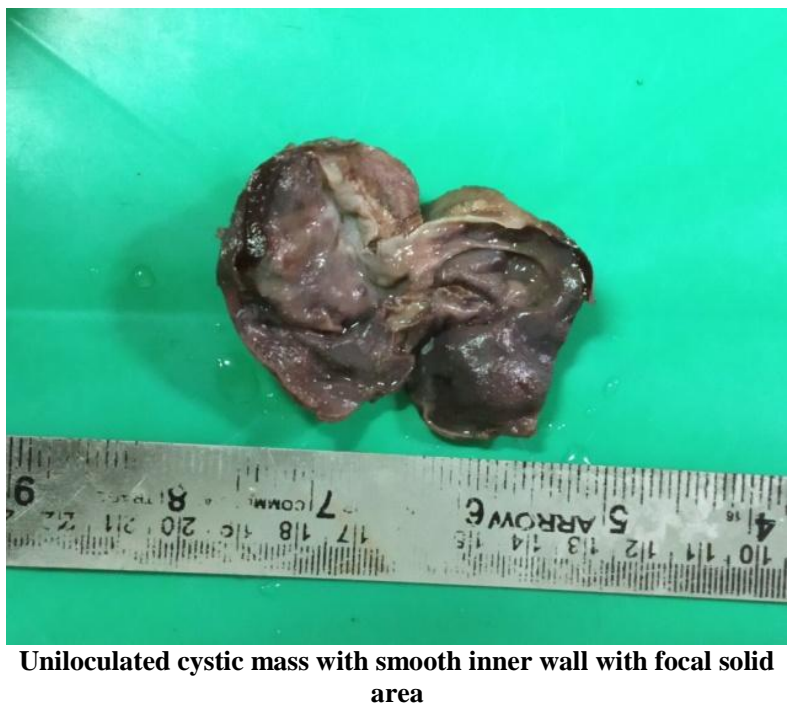

H\&E stained paraffin sections show a cyst lined by stratified squamous epithelium and the fibrocollagenous wall shows lymphoid tissue with germinal centres along with congested blood vessels and hemorrhage.Section from the solid area also showed fibrocollagenous tissue with lymphoid follicles and hemorrhage. A diagnosis of branchial cleft cyst arising from second branchial pouch was made. 


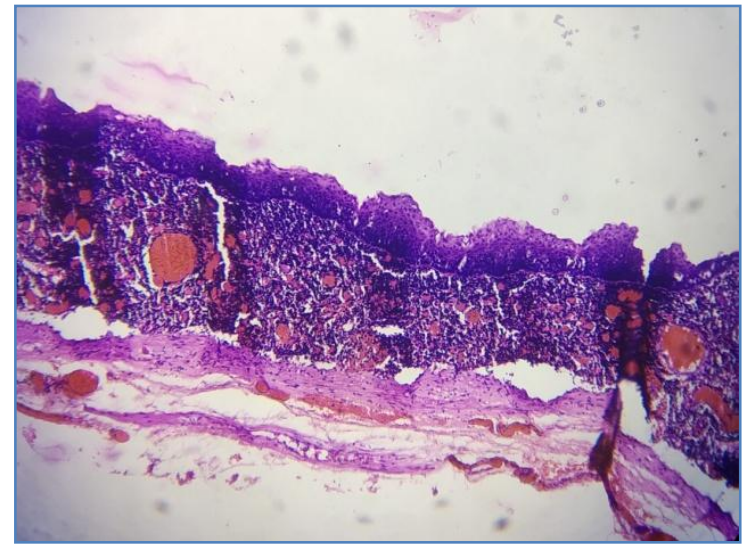

400x: cyst lined by stratified squamous epithelium

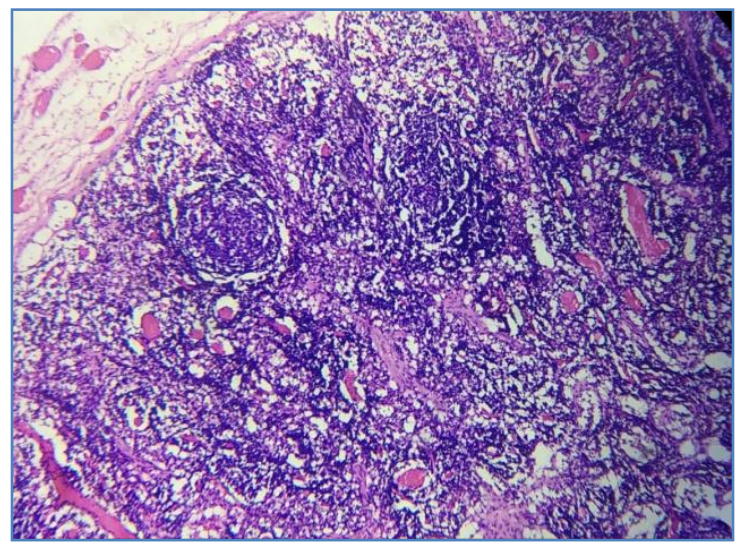

400 xs: cystwall showing lymphoid follicles and congested blood vessels

\section{CASE 3}

A 35 year old man presented with difficulty while swallowing for last 7 months, especially for spicy and hot food. Clinical examination findings were within normal limits, but USG revealed a well-defined cystic mass in the right paratracheal region.It was excised and sent for histopathology. The specimen was received in multiple pieces which were part of a cystic lesion together measuring $5 \times 3 \times 1 \mathrm{~cm}$.No solid area seen.

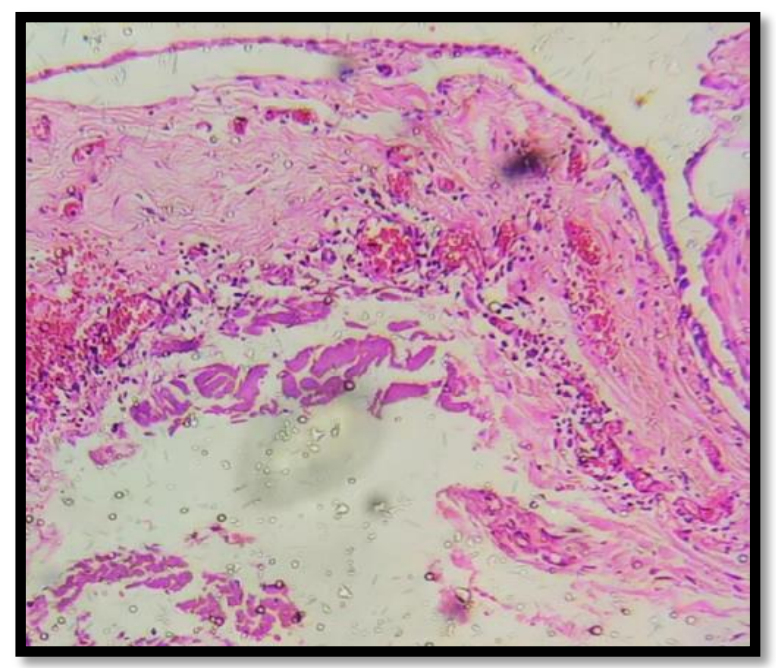

H\&E, 400x-Cyst wall lined by flattened cuboidal epithelium

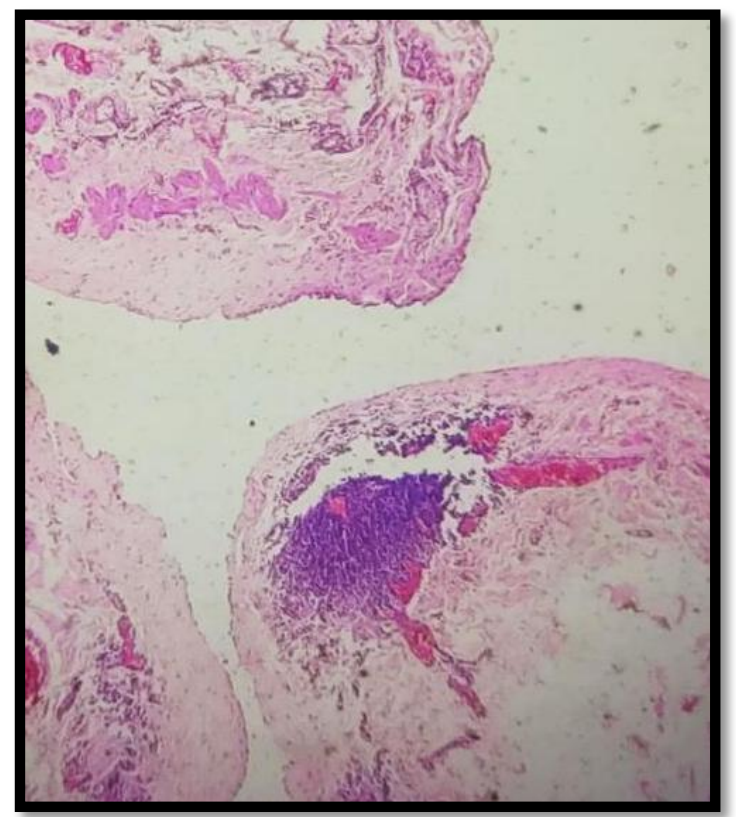

H\&E, $400 \mathrm{x}$-Cyst walls shows lympjoid follicles, smooth muscle and congested blood vessels

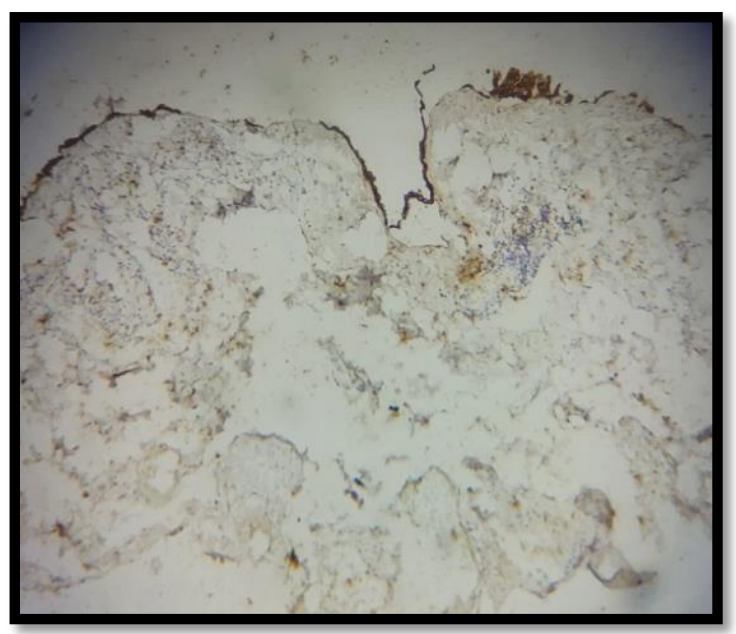

IHC, 400 xs- The lining cells show positivity for CK

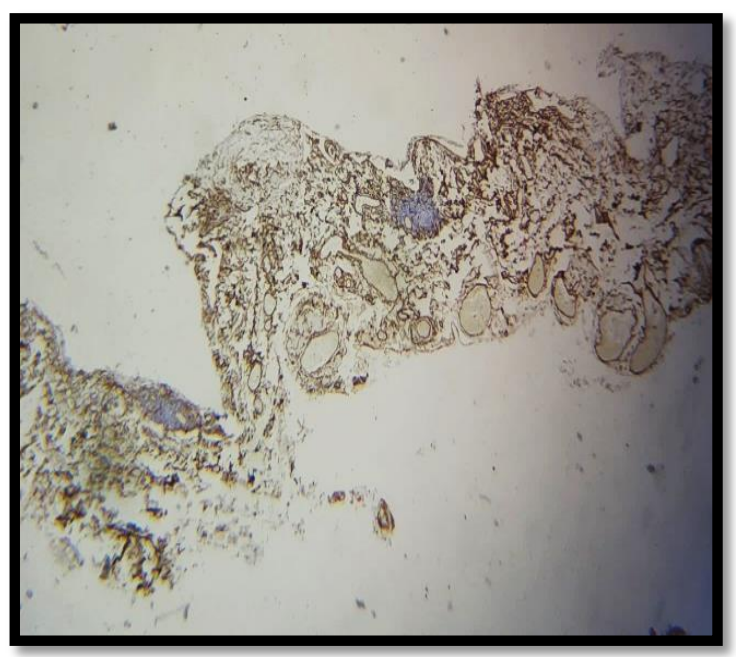

IHC, 400 xs: The lining cells are negative for CD34 with positive internal control. 
H\&E stained paraffin sections showed fragments of a cyst wall lined by flattened cuboidal epithelium, wall of which shows lymphoid follicles, smooth muscle and congested blood vessels. Immunohistochemistry was done to distinguish from lymphangioma using the markers CD 34 and CK. The lining cells were positive for $\mathrm{CK}$ and negative for CD34 with positive internal control. Hence it was diagnosed as branchial cyst.

\section{CASE 4}

A 55 year old man presented with difficulty in swallowing for last 2 months.Clinical examinations were within normal limits. CT scan revealed a welldefined lesion in the right paratracheal region in the antero superior mediastinum measuring $7.6 \times 7 \times 6.3 \mathrm{~cm}$.

Excision was done for the same. We received a collapsed cyst measuring $7 \times 5 \times 5 \mathrm{~cm}$. Cutsection showed a biloculated cyst. Inner wall appeared shaggy. No solid area seen.

H\&E stained paraffin sections showed fibrofatty tissue with a cystic lesion lined by flattened epithelium. Cyst wall shows smooth muscle and focal lymphoid aggregates. No thymic tissue identified. It was diagnosed as benign cystic lesion suggestive of branchial cyst.

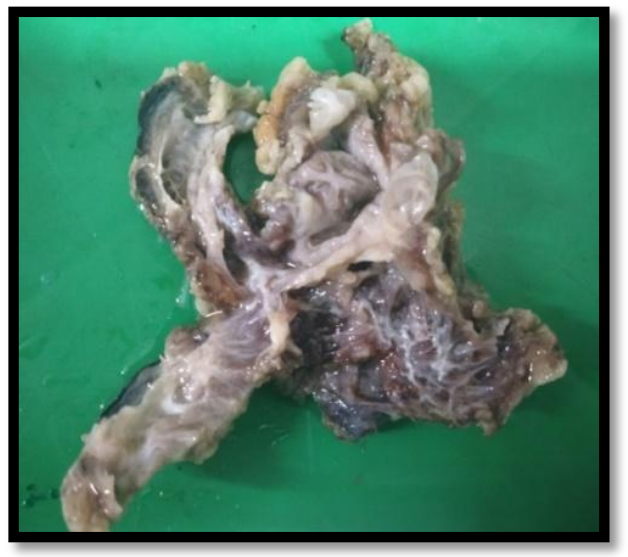

Biloculated cyst with shaggy inner wall

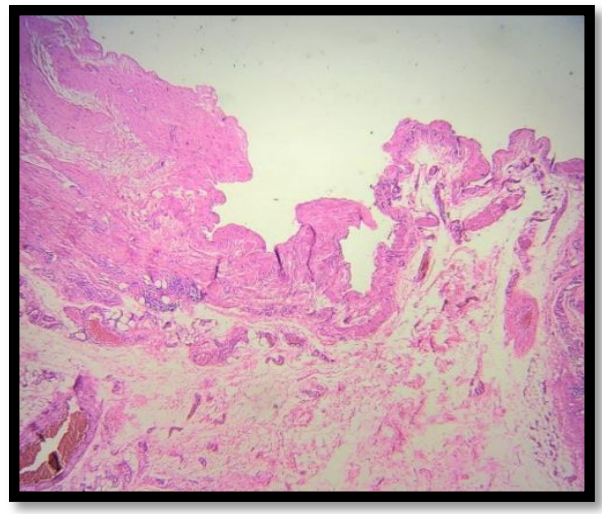

100x-cyst lined by flattened epithelium and wall showing smooth muscle

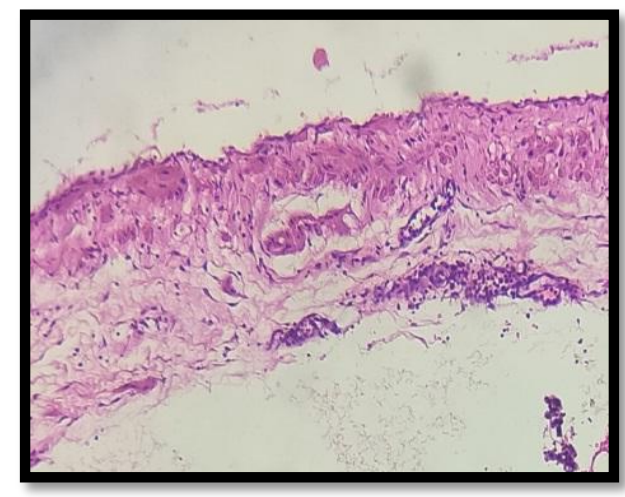

400x-cyst lined by flattened epithelium

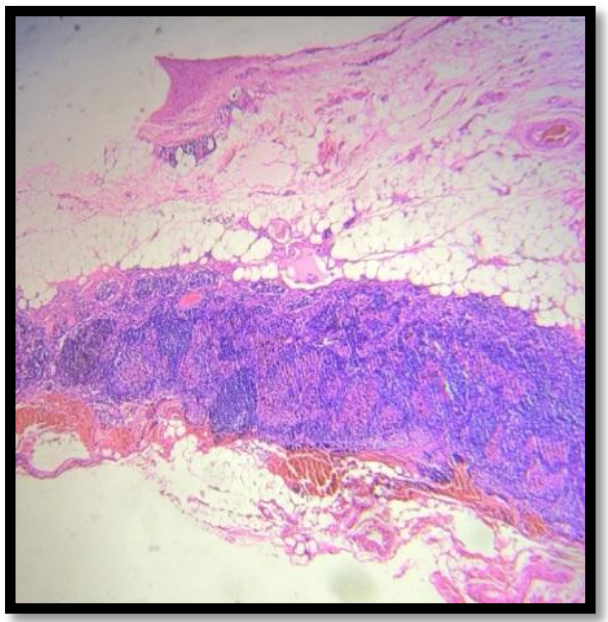

Cyst wall showing lymphoid aggregates

\section{DISCUSSION}

This report describes four different presentations of branchial cleft cysts, arising from second, third and fourth branchial arches. Branchial cysts arising from second arch presenting as neck swelling are the most common among branchial cleft cysts.

Mediastinal cysts are relatively uncommon, accounting for 10 to $15 \%$ of radiologically detected masses at this site. Several tissue types can be seen in such lesions. Sometimes neoplasms that undergo cystic degeneration also may present as a mediastinal cyst. Its unusual presentation in the mediastinum causes a delay in the diagnosis.

Some mediastinal cysts may contain more than one of these constituents, relating to the fact that many intrathoracic cysts are congenital and also to the close proximity in which the embryonic foregut, pleuropericardial membranes and branchial pouches are formed during early morphogenesis.

Branchial cysts may rarely arise within the thyroid gland. $33 \%$ of patients with congenital third branchial arch anomalies and $45 \%$ with fourth branchial arch abnormalities present with acute infectious thyroiditis. 
Patients usually present between 20 to 40 years of age. $20 \%$ of cases are seen in children. $2 \%$ to $3 \%$ of cases are bilateral. Branchial cleft cysts are 10 times more common than fistulas.

The cysts are lined by stratified squamous epithelium/columnar/flattened cuboidal epithelium. Cysts derived from branchial cleft have squamous epithelial lining while cysts derived from branchial pouch have respiratory epithelial lining. But repeated infections may cause squamous metaplasia. The cyst wall shows lymphoid tissue, smooth muscle bundles and rarely sebaceous/mucinous glands. Sometimes the cysts may get infected also.

Differential diagnosis is

- First branchial cleft cyst: epidermoid cyst, dermoid cyst, cystic sebaceous lymphadenoma

- Second branchial cleft cyst: lateral thyroglossal duct cyst
- Third branchial cleft cyst: papillary carcinoma with cystic change.

- Fourth branchial cleft cyst: thymic cyst.

During the surgery the cyst should be followed into the neck and excised completely in case of mediastinal lesions. It will minimise the chance of recurrence, which is usually high following incision and drainage of third and fourth branchial cyst. Recurrence rate is around 5\% and depends on completeness of resection. There are no reported cases of malignancies arising from the branchial cysts.

\section{CONCLUSION}

Branchial cysts should be a differential diagnoses in case of neck and mediastinal cysts. Though branchial cysts arising from second arch is common, rarely it can also arise from third or fourth branchial arches. Complete resection will minimise the recurrence rate.

\begin{tabular}{|l|l|l|l|l|l|l|l|}
\hline $\begin{array}{l}\text { Case } \\
\text { No }\end{array}$ & Age/Sex & $\begin{array}{l}\text { Clinical } \\
\text { presentation }\end{array}$ & Site of the cyst & Size & $\begin{array}{l}\text { Lining of the } \\
\text { cyst in histology }\end{array}$ & $\begin{array}{l}\text { Finding in the } \\
\text { cyst wall }\end{array}$ & $\begin{array}{l}\text { Possible } \\
\text { arch of } \\
\text { origin }\end{array}$ \\
\hline $\begin{array}{l}\text { Case } \\
1\end{array}$ & $\begin{array}{l}51 / \\
\text { female }\end{array}$ & Pneumonia & $\begin{array}{l}\text { Superior } \\
\text { mediastinum }\end{array}$ & $\begin{array}{l}5 \times 2.5 \times 1.5 \\
\mathrm{~cm}\end{array}$ & $\begin{array}{l}\text { Hyperkeratotic } \\
\text { stratified } \\
\text { squamous } \\
\text { epithelium }\end{array}$ & $\begin{array}{l}\text { Smoothmuscle, } \\
\text { lymphoid tissue }\end{array}$ & $3^{\text {rd }}$ or $4^{\text {th }}$ \\
\hline $\begin{array}{l}\text { Case } \\
2\end{array}$ & $21 /$ male & $\begin{array}{l}\text { Swelling } \\
\text { neck }\end{array}$ & $\begin{array}{l}\text { Anterior border of } \\
\text { sternocleidomastoid }\end{array}$ & $5 \times 4 \times 2 \mathrm{~cm}$ & $\begin{array}{l}\text { Stratifed } \\
\text { squamous } \\
\text { epithelium }\end{array}$ & Lymphoid tissue & $2^{\text {nd }}$ \\
\hline $\begin{array}{l}\text { Case } \\
3\end{array}$ & $35 / \mathrm{male}$ & $\begin{array}{l}\text { Difficulty in } \\
\text { swallowing }\end{array}$ & $\begin{array}{l}\text { Right paratracheal } \\
\text { region }\end{array}$ & $5 \times 3 \times 1 \mathrm{~cm}$ & $\begin{array}{l}\text { Flattened } \\
\text { cuboidal } \\
\text { epithelium }\end{array}$ & $\begin{array}{l}\text { Smooth } \\
\text { muscle,lymphoid } \\
\text { follicle }\end{array}$ & $3^{\text {rd }}$ or $4^{\text {th }}$ \\
\hline $\begin{array}{l}\text { Case } \\
4\end{array}$ & $55 /$ male & $\begin{array}{l}\text { Difficulty in } \\
\text { swallowing }\end{array}$ & $\begin{array}{l}\text { Right paratracheal } \\
\text { region }\end{array}$ & $\begin{array}{l}7.6 \times 7.6 \times 6 . \\
3 \mathrm{~cm}\end{array}$ & $\begin{array}{l}\text { Flattened } \\
\text { cuboidal } \\
\text { epithelium }\end{array}$ & $\begin{array}{l}\text { Smooth muscle, } \\
\text { lymphoid } \\
\text { aggregates }\end{array}$ & $3^{\text {rd }}$ or $4^{\text {th }}$ \\
\hline
\end{tabular}

\section{REFERENCES}

1. Kotecha, V., Muturi, A., \& Ruturi, J. (2015). Branchial cysts: an unusual cause of a mediastinal mass: a case report. Journal of medical case reports, 9(1), 208.
2. Khan, S., Viana, D., Júnior, J., Siqueira, A., Veríssimo, C., Calábria, E., \& Lima, L. (2019). Epôster. Journal of Indian Association of Pediatric Surgeons, 24, 1.

3. Nicoucar, K., Giger, R., Jaecklin, T., Pope Jr, H. G., \& Dulguerov, P. (2010). Management of congenital third branchial arch anomalies: a systematic review. Otolaryngology-Head and Neck Surgery, 142(1), 21-28. 